\title{
Remanufacturing System: Characterizing the Reverse Supply Chain
}

\author{
Ana Paula B. Barquet ${ }^{1}$, Henrique Rozenfeld ${ }^{1}$, and Fernando A. Forcellini ${ }^{2}$ \\ ${ }^{1}$ Escola de Engenharia de São Carlos, Universidade de São Paulo, \\ Rua Trabalhador São Carlense, 400, CEP 13566-590, São Carlos, Brazil \\ anabarquet@gmail.com \\ ${ }^{2}$ EPS/CTC/ UFSC, Campos Universitário, \\ Universidade Federal de Santa Catarina, CEP 88040- 970, Florianópolis, Brazil
}

\begin{abstract}
End-of-life strategies, such as remanufacturing, have gained ground in order to promote product reuse, reduce environmental impacts and costs, as well as to win new markets. The remanufacturing process preserves part of the product's raw materials and added value during its manufacturing. This study addresses the system that includes remanufacturing in order to understand it and to define its elements, as well as to characterize the supply chain that permeates and leads to the effective functioning of this system. To this end, a Systematic Literature Review on remanufacturing was conducted. Moreover, the RS proposed was based on the General Systems Theory.
\end{abstract}

Keywords: Remanufacturing, Reverse Supply Chain, System, Elements.

\section{Introduction}

Increased competition in the market, environmental concerns, changing customer requirements and the emergence of new laws regarding the products' end-of-life management has led companies to seek new operation models to maintain and expand their market share [1] [2]. Thus, adopting end-of-life strategies for products, as for instance remanufacturing, have become increasingly important in today's business operations.

The remanufacturing process preserves part of the product's raw materials and added value during its manufacturing, which enables productivity and profit gains for the companies [3]. Additionally, due to its environmental benefits, remanufacturing is increasingly gaining ground on the world stage.

However, companies often encounter difficulties in implementing remanufacturing due to the lack of knowledge on the subject [4], the lack of strategic remanufacturing issues [5] and studies that indicate how to implement it [6]. This issue is new to Brazilian companies and is still in the exploratory phase, therefore justifying the importance to conduct a structured literature review on remanufacturing.

Furthermore, the overall outlook on matters relating to remanufacture in an integrated and systematic manner is not an easy task. A system is a set of interdependent elements that interact to reach an objective and perform a determined function [7] and considered to be the elements and the relationships between them which determine how the system works, forming a whole unit that is organized and 
complex [8]. This demonstrates the need to develop a model for the Remanufacturing System (RS). This need particularly falls on the importance of understanding how the supply chain for remanufacturing works, which requires integrating different players and implementing various activities [2] to reach a successful RS operation.

Taking into account the aforementioned facts, it is possible to observe the importance of regarding remanufacturing as a system, as well as its elements, features, players, challenges and practices, in order to assist the implementation of this system into organizations and also to provide an outline of the activities and players that make this system work through the supply chain. Thus, the objective is to identify the elements that comprise this system to then characterize the supply chain associated to it.

Below is the work methodology used to develop this study.

\section{Methodology}

The study herein was conducted using the Systematic Literature Review [9]. Therefore, articles were searched that addressed the words: Remanufacture; Remanufacturing; Remanufactured; Design for environment; Design for remanufacturing; Reverse logistics; Product recovery; Reverse supply chain; Closed loop; Closed loop supply chain; End of life; Lifecycle, as well as the translation of these words into Portuguese. 223 abstracts of the studies found were read, of which 91 research studies that dealt with practices to implement remanufacturing were selected and 24 were used because they presented remanufacturing practices related to reverse supply chain.

Since these elements are to be presented within a systemic outlook, the General Systems Theory was used, whose objective is to study the elements that comprise a system, as well as the interaction between them [10]. Given that, this interaction is critical to understanding the system as a whole [7].

Thus, after completing RBS on remanufacturing, the organization of concepts was carried out to obtain the definition and characterization of the Remanufacturing System and of the elements inserted into this system, presented below.

\section{Remanufacturing System}

Based on the literature, the Remanufacturing System (RS) in this study is addressed as a system that encompasses all the elements involved in remanufacturing, from the reverse supply chain steps up to the return of the already remanufactured products to be sold on the market [11]. The elements and sub-elements adopted in this work are:

- Element 1: Remanufacturing Design;

- Element 2: Reverse supply chain (RSC)

- Sub-element 2.1: Relationship with the supplier of the used product;

- Sub-element 2.2: Reverse Logistics;

- Element 3: Remanufacturing Operation;

- Element 4: Sales of the remanufactured product;

- Element 5: Information flow in the Remanufacturing System;

- Element 6: Employees' knowledge and skills on remanufacturing. 
Figure 1 shows the Remanufacturing System model developed in this research work. The first element is the Remanufacturing Design, a part of the Product Development Process, aimed at facilitating remanufacturing. The Reverse Supply Chain is composed of two sub-elements: acquisition/relationship with the used product supplier and reverse logistics. The main players in this system are the customers who purchased the new product and that become the supplier of the product's end of life, the player responsible for reverse logistics, the company responsible for the remanufacturing and selling of the remanufactured product and the customer who buys such a product.

The information flow in the RS is considered an element that permeates and interconnects all the others. It should also be considered that the employees' remanufacturing Knowledge and Skills are crucial for the system and should be present in all the processes.

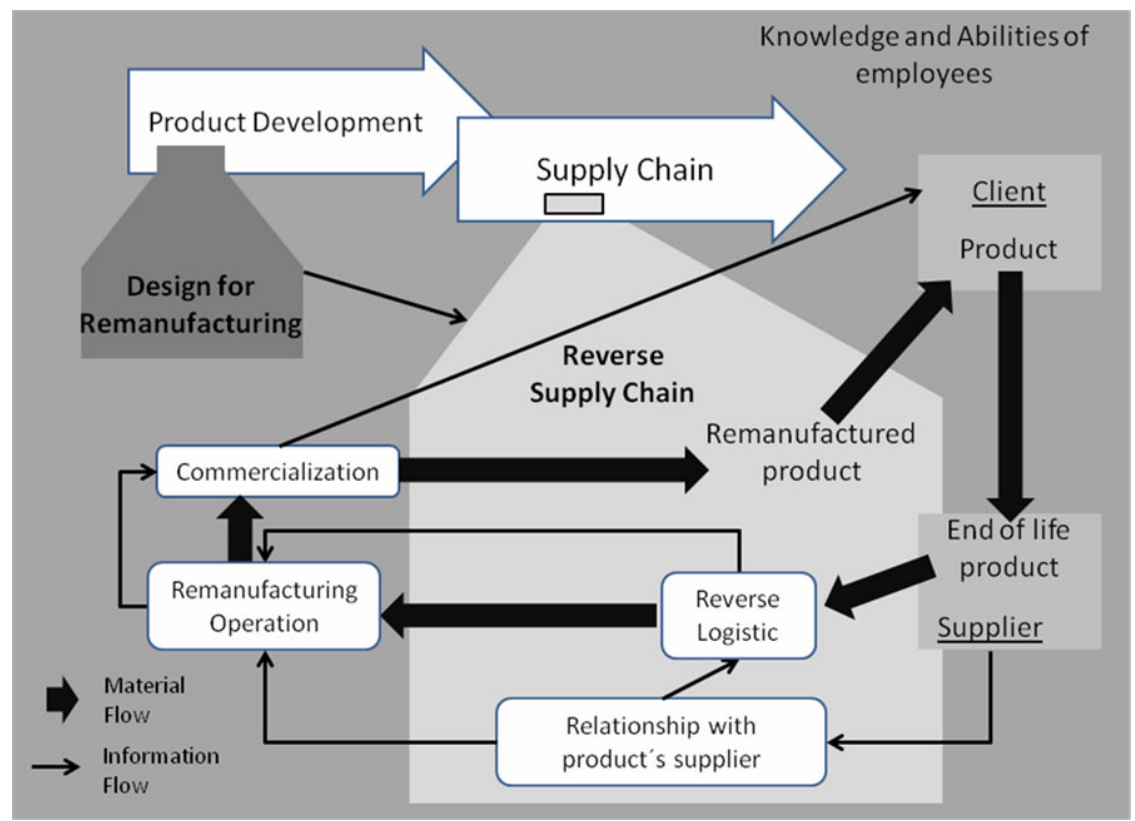

Fig. 1. Remanufacturing System Model

After presenting remanufacturing as a system, the next section focuses specifically on the reverse supply chain as well as on the analysis and description of this element and its sub-elements.

\subsection{Reverse Supply Chain (RSC) for Remanufacturing}

According to Guide and Van Wassenhove [12], reverse supply chain (RSC) is the set of steps necessary to collect a used product, followed by the desired end-of-life strategy application (remanufacturing, reuse, recycling or disposal) [2]. The RSC 
begins with the collection of products from customers and/or companies in different links of the supply chain, given that the collection sources tend to be geographically dispersed. Next, there is the inspection stage or the tests performed at the collection site, at a receiving center or place where the product will be recycled and reused. At this point, the fate of the recovered product is decided, which has various reuse possibilities, such as remanufacturing [13].

\section{- Difficulties and practices}

Leite [14] reports that the RSC stages are treated as a series of independent and isolated steps, without considering their integrated nature. Moreover, with regard to RSC, both in business and in academia, little is being undertaken concerning its strategic issues [2]. Most research studies address technical and operational issues, since focusing on the technical activities is considered attractive for initial investigations [15].

Some of the features of Reverse Supply Chain make it difficult to manage and plan its stages and activities. For example, when a company collects the used products, its provider is usually the final customer, which complicates the access to the appropriate number of products at the time of return. Another complication is that the quality of used products varies, hence requiring efficient inspection [16]. Moreover, there is the need to disassembly the products collected, structure a reverse logistics network and deal with the high processing time variability [17].

Some recommendations to achieve efficiency in the reverse supply chain are: (i) to structure a specialized team to have contact with the supplier of the used product, (ii) to perform demand prediction for the products' return time, using its sales and lifetime as a base and (iii) to align the RSC with the Direct Supply Chain and achieve effectiveness in the activities of the closed Supply Chain Flow [18].

\section{- Interdependence and interaction with other RS elements}

The degree of structuring of a RSC can be defined depending on the existence of structured organizational practices relating to the return of the used products, the relationships between companies belonging to the reverse chain, as well as the level of resources made available by these companies, as for example, employee skills for remanufacturing [6] [13] [14] [19].

The appropriate management of reverse chains can also serve as an excellent source of information about the customers' habits and expectations [13]. Next, the sub-elements of the reverse supply chain are discussed.

\subsubsection{Sub-Element 2.1: Relationship with the Supplier of the Used Product}

Sundin [20] cites that the relationship of the remanufacturer with its used products supplier is an important aspect to the effectiveness of the business. If the recovered product is intended for remanufacturing, it is important that before the product is selected to return to the reverse flow, a "pretrial" of its remanufacturing should be performed to prevent it from being transported without the proper conditions to be reused, which would generate additional costs. This trade-off between the potential for reuse and additional costs is difficult to predict and to do this, employees with certain skills and experiences are needed [21]. The large number of small-quantity 
suppliers of used products and the manifold conditions of these products makes quality control difficult by the companies that receive them for remanufacturing.

There are cases when the raw-material suppliers for Remanufacturing Operations are the consumers themselves, who discard the product due to the end of its useful life or due to other reasons, such as the launching of a more modern product. In this case, there are some problems regarding the lack of incentive these customers receive to return the used products to remanufacturing companies [22], such as the lack of contact the remanufacturer has with the customer [23] and the consumer's lack of information and trust regarding remanufacturing [24], as for instance the economic and environmental advantages of remanufacturing. Thus, companies that desire to have success with remanufacturing need to have strategies that encourage the consumers to return these items [23].

\subsubsection{Sub-Element 2.2: Reverse Logistics (RL)}

According to the Council of Logistics Management [19], Reverse Logistics is the process of effectively planning, implementing and controlling the flow of components, materials under processing, the final product and related information from the consumption point to the point of origin, with the objective of recovering and adding value or achieving the most appropriate disposal [18]. Adding value can be of various types: economic, ecological, corporate image, among others [14].

$\mathrm{RL}$ is a major challenge for RS, due to the difficulty to predict the return volume and timing and the products' quality conditions, making Remanufacturing Operation difficult to plan [1]. Some of the difficulties in implementing RL by businesses are: the lack of a system that integrates direct logistic activities with those of reverse logistics [25], difficulty in measuring the impact and controlling the return of the products and materials and the fact that the reverse flow is considered a cost for companies, thus receiving little or no priority as a business strategy [19]; the lack of studies by companies to assess the impacts of the RL practices in the success of organizations [26]; the relationship between the players involved in the activities of reverse logistics is not very structured; there is low proximity between the factories and suppliers of used products; and the freight costs are higher due to the lower volumes transported [27].

Unlike the distribution in direct logistics, which is designed to carry large volumes of the same product from the producer to a few local clients, in reverse logistics the volume may considerably low. This can set back the economy in the transport. Another aspect to consider is that unlike direct logistics, the used products that are collected are not packaged and are therefore unprotected and at risk of damage, which limits its reuse. Thus, a packaging system is necessary to protect the product [21].

Pires [27] raises other drawbacks to RL, such as the tendency for products to remain longer in the reverse channels, which results in higher inventory, transportation and storage costs, as well as the decrease in revenue due to the possibility of obsolescence and degradation of the product.

According to Lacerda [28], the six major factors to minimize the challenges of reverse logistics activities are:

- good entry and exit controls;

- mapped and formalized processes;

- reduced cycle times; 
- accurate information systems;

- planned logistics network and;

- collaborative relationships between customers and suppliers.

Reverse logistic activities require skills to properly execute the transportation, storage and stockpiling of used products, in addition to information on how the product was designed.

\section{Conclusions and Contributions}

This work enabled to organize the knowledge on remanufacturing through the proposition of the Remanufacturing System concept and the elements included in this system. It was also highlighted the characteristics of reverse supply chain involved in the RS, indicating the related steps, actors, practices and difficulties and the importance of relationship of the remanufacturer with used products users and reverse logistics to the success of the entire system.

When investigating the literature that addresses remanufacturing, no model was found that integrates remanufacturing issues in a system or that broached the elements that are part of a Remanufacturing System. This work consolidated and organized the elements of this system, enabling a better understanding of remanufacturing by highlighting the chain and the main interdependencies between the elements.

Therefore, the RS proposed contributes to an integrated outlook and to the expansion of theoretical knowledge on the subject. Such contributions are intended to facilitate the development of future works in this area, as well as to assist companies that are structuring remanufacturing practices or intend to start them.

Moreover, this work aims to stimulate the development of studies on remanufacturing and the supply chain for remanufacturing in Brazil, since there are few domestic companies that remanufacture and few studies on remanufacturing. Additionally, this work seeks to encourage companies to implement remanufacturing, as this study provides a holistic outlook on the operation of this system with features of its supply chains.

With regards to the supply chain for the Remanufacturing System, some of its features and difficulties were shown. For future works, it is then recommended that the practices that seek to overcome such difficulties should be studied and analyzed. Besides, studies on remanufacturing companies are required to demonstrated the status of remanufacturing in Brazil.

\section{References}

1. Kato, P., Laurindo, F.J.B.: Discutindo o Planejamento Integrado de uma Remanufatura em um ciclo fechado de Supply Chain. XXIV ENEGEP (Encontro Nacional de Engenharia de Produção), Florianópolis, SC (2004)

2. Guide Jr., V.D.R., Harrison, T.P., Van Wassenhove, L.N.: The Challenge of Closed-Loop Supply Chains. 33(6), 3-6 (2003)

3. Giuntini, R., Gaudette, K.: Remanufacturing: The next great opportunity for boosting US productivity. Business Horizons (2003) 
4. Zanette, E.T.: A Remanufatura no Brasil e no Mundo: Conceitos e Condicionantes. 2008. Monografia (Graduação em Engenharia Ambiental) - Escola de Engenharia de São Carlos, Universidade de São Paulo, São Carlos, SP (2008)

5. Ferguson, M.E., Toktay, L.B.: The Effect of Competition on Recovery Strategies. Technology and Operations Management, INSEAD (2004)

6. Jacobsson, N.: Emerging Product Strategies: Selling services of remanufactured products. Dissertação. The International Institute of Industrial Environmental Economics, Lund University, Sweden (2000)

7. Oliveira, J.P., Portela, L.O.V.: A Cidade Como Um Sistema: Reflexões Sobre a Teoria Geral de Sistemas Aplicada à Análise Urbana. Perspectivas Contemporâneas. Revista eletrônica de ciências sociais aplicadas 1(2), 164-182 (2006)

8. Johnson, R.A., Kast, F.E., Rosenweig, J.E.: The theory and management of systems. International Student Edition, Mc Graw-Hill, New York (1963)

9. Biolchini, J., et al.: Systematic Review in Software Engineering. Technical Report Rt - Es 679/05. Rio de Janeiro: Systems Engineering and Computer Science Department, Universidade Federal do Rio de Janeiro (2005)

10. Bertalanffy, V.L.: Teoria Geral dos Sistemas. Vozes, Petrópolis (1975)

11. Östlin, J.: On Remanufacturing Systems: Analysing and Managing Material Flows and Remanufacturing Processes. Dissertação (Mestrado em Administração e Engenharia) Universidade de Linköping, Suécia (2008)

12. Guide Jr., V.D.R., Van Wassenhove, L.N.: The reverse supply chain. Harvard Business Review 80(2), 25-26 (2002)

13. Leite, P.R., et al.: O papel dos ganhos econômicos e de imagem corporativa na estruturação dos canais reversos. Gestão.Org 4(4) (2006)

14. Leite, P.R.: Logística Reversa: meio ambiente e competitividade. Prentice Hall, São Paulo (2003)

15. Guide Jr., V.D.R., Van Wassenhove, L.N.: The Evolution of Closed-Loop Supply Chain Research. Operations Research 57(1), 10-18 (2009)

16. Guide Jr., V.D.R.: Production planning and control for remanufacturing: industry practice and research needs. Journal of Operations Management 18, 467-483 (2000)

17. Guide Jr, V.D.R., Jayaraman, V., Linton, J.D.: Building contingency planning for closedloop supply chains with product recovery. Journal of Operations Management (2002)

18. Fioravanti, R.D., Carvalho, M.F.H.: Aplicações de modelos de cadeia reversa em uma operação de serviços: estudo de caso no setor de serviços de impressão. XI SIMPOI (Simpósio de Administração da Produção, Logística e Operações Internacionais) (2008)

19. Rogers, D.S., Tibben-Lembke, R.S.: Going backwards: reverse logistics practices and trends. Reverse Logistics Executive Council, Reno (1998)

20. Sundin, E., et al.: Remanufacturing of Products used in Product Service System Offerings. In: The 41st CIRP Conference on Manufacturing Systems (2008)

21. Ferrer, G., Whybark, D.C.: From Garbage to Goods: Successful Remanufacturing Systems and Skills. Business Horizons (2000)

22. King, A.M., Burguess, S.C.: The development of a remanufacturing platform design: a strategic response to the Directive on Waste Electrical and Electronic Equipment. Proc. IMechE Part B: Journal of Engineering Manufacture 219, 623-631 (2005)

23. Östlin, J., Sundin, E., Björkman, M.: Importance of closed-loop supply chain relationships for product remanufacturing. International Journal of Production Economics (115), 336348 (2008)

24. Seitz, M.S.: A critical assessment of motives for product recovery: the case of engine remanufacturing. Journal of Cleaner Production 15, 1147-1157 (2006) 
25. Daher, C.E., Silva, E.P.S., Fonseca, A.P.: Logística Reversa: Oportunidade para Redução de Custos através do Gerenciamento da Cadeia Integrada de Valor. Brazilian Business Review 3(1) (January/June 2006)

26. Miguez, E., Mendonça, F.M., Valle, R.A.B.: Impactos ambientais, sociais e econômicos de uma política de logística reversa adotada por uma fábrica de televisão: um estudo de caso. XXVII ENEGEP (Encontro Nacional de Engenharia de Produção), Foz do Iguaçú, PR, Brasil (2007)

27. Pires, N.: Modelo para a logística reversa dos bens de pós-consumo em um ambiente de cadeia de suprimentos. 2007. Tese (Doutorado em Engenharia de Produção) - Curso de Pós-Graduação em Engenharia de Produção, UFSC, Florianópolis (2007)

28. Lacerda, L.: Logística reversa, uma visão sobre os conceitos básicos e as práticas operacionais. Centro de Estudos em Logística. COPPEAD, UFRJ (2004) 